\title{
Analysis of intraflagellar transport in the zebrafish model
}

\author{
C Zhao $^{1 *}$, Y Omori ${ }^{2}$, K Brodowska $^{1}$, P Kovach ${ }^{1}$, J Malicki ${ }^{3}$ \\ From First International Cilia in Development and Disease Scientific Conference (2012) \\ London, UK. 16-18 May 2012
}

The formation and function of cilia requires that proteins are translocated by intraflageller transport (IFT) along microtubules that support ciliary structure. Using tools of genetic analysis in zebrafish, we studied both motors that drive IFT and proteins that mediate the interaction of the IFT particle with presumptive cargo molecules. Our studies demonstrate that IFT particle components, and a Meckel-Gruber Syndrome 1 (MKS1)-related, B9 domain protein, $\mathrm{B} 9 \mathrm{~d} 2$, bind each other and contribute to the ciliary localization of Inversin (Nephrocystin 2). B9d2, Inversin, and Nephrocystin 5 support, in turn, the transport of a cargo protein, Opsin, but not another photoreceptor ciliary transmembrane protein, Peripherin. In parallel, we studied motors that drive the movement of the IFT particle, and found that kinesin 2 family motors, kif3 and kif17, display very different contributions to ciliogenesis. While kif17 appears largely dispensable, the kif3b gene is necessary for cilia differentiation in most tissues, although exceptions exist, and include photoreceptors and a subset of hair cells. Cilia of these cell types persist even in kif3b/kif17 double mutants. In contrast to kif3b/kif17 double homozygotes, simultaneous interference with kif3b and kif3c leads to the complete loss of photoreceptor and hair cell cilia, revealing redundancy of function. Moreover, our data suggest that the repertoire of kinesin motors changes in photoreceptors during their differentiation. These studies reveal molecular mechanisms that mediate the transport of ciliary proteins, and are of fundamental importance for the formation and function of several vertebrate organs.

\footnotetext{
Author details

${ }^{1}$ Tufts University, USA. ${ }^{2}$ Osaka Biosciences Institute, Osaka, Japan.

${ }^{3}$ Department of Biomedical Science and the MRC Centre for Developmental and Biomedical Genetics, University of Sheffield, Sheffield, UK.
}

${ }^{1}$ Tufts University, USA

Full list of author information is available at the end of the article
Published: 16 November 2012

doi:10.1186/2046-2530-1-S1-011

Cite this article as: Zhao et al:: Analysis of intraflagellar transport in the zebrafish model. Cilia 2012 1(Suppl 1):O11.
Submit your next manuscript to BioMed Central and take full advantage of:

- Convenient online submission

- Thorough peer review

- No space constraints or color figure charges

- Immediate publication on acceptance

- Inclusion in PubMed, CAS, Scopus and Google Scholar

- Research which is freely available for redistribution

Submit your manuscript at www.biomedcentral.com/submit
() Biomed Central
C Biomed Central

(c) 2012 Zhao et al; licensee BioMed Central Ltd. This is an Open Access article distributed under the terms of the Creative Commons Attribution License (http://creativecommons.org/licenses/by/2.0), which permits unrestricted use, distribution, and reproduction in any medium, provided the original work is properly cited. 